\title{
Genome size, chromosome number, and rDNA organisation in Algerian populations of Artemisia herba-alba (Asteraceae), a basic plant for animal feeding facing overgrazing erosion
}

\author{
Youcef Bougoutaia ${ }^{1,2}$, Sònia Garcia ${ }^{3,4}$, Teresa Garnatje ${ }^{4}$, Meriem Kaid-Harche ${ }^{1}$ \& Joan Vallès ${ }^{3, *}$ \\ ${ }^{1}$ Laboratoire des Productions Valorisations Végétales et Microbiennes, Département de Biotechnologie, Faculté des Sciences de la \\ Nature et de la Vie, Université des Sciences et de la Technologie d'Oran Mohamed Boudiaf, B.P. 1505, El M'Naouar, Oran 31000, Algeria; \\ youcefb7@gmail.com; kaidharche@yahoo.fr \\ ${ }^{2}$ Faculté des Sciences de la Nature et de la Vie, Université de Djelfa, Cité Aîn Chih, BP 3117, Djelfa 17000, Algeria \\ ${ }^{3}$ Laboratori de Botànica - Unitat Associada CSIC, Facultat de Farmàcia i Ciències de l'Alimentació, Universitat de Barcelona, Av. Joan XXIII s.n., \\ 08028 Barcelona, Spain; soniagarcia@ibb.csic.es; joanvalles@ub.edu
}

${ }^{4}$ Institut Botànic de Barcelona (IBB-CSIC-ICUB), Passeig del Migdia s.n., Parc de Montjuïc, 08038 Barcelona, Spain; tgarnatje@ibb.csic.es Recibido: 26-V-2015; Aceptado: 21-XII-2015; Publicado on line: 23-XI-2016

\begin{abstract}
Bougoutaia, Y., Garcia, S., Garnatje, T., Kaid-Harche, M. \& Vallès, J. 2016. Genome size, chromosome number, and rDNA organisation in Algerian populations of Artemisia herba-alba (Asteraceae), a basic plant for animal feeding facing overgrazing erosion. Anales Jard. Bot. Madrid 73(2): e043.

Artemisia herba-alba is a largely-distributed and often landscape-dominating taxon in arid areas of the Mediterranean and Irano-Turanian regions. In Algeria, in 2010 its communities covered $10 \%$ of the steppe territory, but its populations have been subjected to overgrazing. A karyological study based on 22 populations together with a cytogenetic characterisation of this species has been performed for the first time in Algerian materials, through genome size and chromosome number determination. Fluorescence in situ hybridisation (FISH) was also used to assess the rDNA loci number and distribution in the two ploidy levels detected. The studied accessions are diploid $(2 n=2 x=18$ chromosomes, 6 populations) or tetraploid ( $2 n=4 x=36$ chromosomes, 15 populations). One population, occupying a more or less central geographic position among the studied area, presented both cytotypes. Genome size reflects well the two ploidy levels, with no evidence of downsizing with polyploidy. The karyotypes are rather symmetric (2A Stebbins' class). FISH analyses detected four signals (2 loci) in diploid and eight signals (4 loci) in tetraploid cytotypes for both ribosomal DNA genes, which present an L-type (linked) organisation, i.e. with loci from both rDNA genes colocalised. The presence of two ploidy levels suggest a genomic dynamism and even a possible differentiation underlying the morphological uniformity and despite the dramatic decrease experienced by this plant in Algeria in terms of surface coverage.
\end{abstract}

Keywords: Anthemideae, Artemisia herba-alba, chromosome number, cytogenetics, fluorescent in situ hybridisation, genome organisation, genome size, karyology, polyploidy, rDNA loci.

\section{Resumen}

Bougoutaia, Y., Garcia, S., Garnatje, T., Kaid-Harche, M. \& Vallès, J. 2016. Tamaño del genoma, número cromosomático y organización del rDNA en poblaciones argelinas de Artemisia herba-alba (Asteraceae), una planta básica para la alimentación animal en el contexto de la erosión por sobrepastoreo. Anales Jard. Bot. Madrid 73(2): e043.

Artemisia herba-alba es un taxon ampliamente distribuido y dominante en el paisaje en áreas áridas de las regiones mediterránea e irano-turania. En Argelia, sus comunidades cubrían en 2010 el 10\% de su territorio de estepa, pero sus poblaciones se encuentran sometidas a sobrepastoreo. Se ha llevado a cabo un estudio cariológico basado en 22 poblaciones, se han caracterizado citogenéticamente por primera vez poblaciones argelinas de esta especie y se ha estimado el tamaño del genoma y el número cromosomático, además de la determinación por hibridación in situ fluorescente (FISH) del número y la distribución de los loci del ADN ribosómico en los dos niveles de ploidía. Las accesiones estudiadas son diploides $(2 n=2 x=18,6$ poblaciones $)$ o tetraploides $(2 n=4 x=36$, 15 poblaciones), y una, que ocupa una posición más o menos céntrica entre las consideradas, presenta ambos niveles de ploidía. El tamaño del genoma refleja los dos niveles de ploidía y no se observan indicios de disminución con la poliploidía. Los cariotipos son simétricos (clase 2A de Stebbins). Los análisis de FISH detectan cuatro señales (2 loci) en los citotipos diploides y ocho señales (4 loci) en los tetraploides para ambos genes del ADN ribosómico, que presenta una organización del tipo L (ligada), es decir, con los loci de los dos genes del ADNr colocalizados. La presencia de dos niveles de ploidía sugiere un dinamismo genético e incluso una posible diferenciación más allá de la uniformidad morfológica, con independencia del retroceso experimentado por esta planta en Argelia.

Palabras clave: Anthemideae, Artemisia herba-alba, cariología, citogenética, hibridación in situ fluorescente, loci del ADN ribosómico, número cromosómico, organización del genoma, poliploidía, tamaño del genoma.

Copyright: () 2016 CSIC. This is an open-access article distributed under the terms of the Creative Commons Attribution (CC-by) Spain 3.0 License

\section{INTRODUCTION}

Artemisia is one of the biggest genera in the family Asteraceae, with around 500-600 taxa at specific and subspecific levels and organised in five subgenera (Vallès \& al., 2011). Artemisia herba-alba Asso belongs to $A$. subgenus Seriphidium (Besser ex Less.) Rouy (A. sect. Seriphidium Besser ex Less., basión.) and is basically distributed in the
Mediterranean region. It has been referred to as a species complex, with closely related taxa considered as independent species in the Irano-Turanian region, or as a single species (Vallès, 1987; Ouyahya \& Viano, 1988; Podlech, 2013).

In Algeria, $A$. herba-alba, locally called chib in Arabic and armoise blanche in French, occurs mostly in lime-sandy soils with $200-600 \mathrm{~mm}$ of mean annual precipitation, across the

\footnotetext{
* Corresponding author.
} 
so-called steppe areas ranging from upper semiarid to lower perarid (or Saharian) in the bioclimatic range (Pouget, 1980; Aidoud, 1988).

According to the Algerian Haut commissariat au développement de la steppe (HCDS), A. herba-alba covers 2 million hectares in Algeria, i.e., ca. $10 \%$ of all steppe surface of the country, but this represents a $30 \%$ reduction as compared with the situation in 1970 (HCDS, 2010). Nedjimi \& Guit (2012) estimated in 3 million hectares the extension of $A$. berba-alba in Algeria. In any case, it is the second most consumed species by domestic animals - mostly sheep — after Stipa tenacissima L. (with 4 million hectares) and plays a relevant role in rural areas economy and development (Houmani \& al., 2004; HCDS, 2010; Nedjimi \& Guit, 2012). Its regression is being replaced by scarcely-palatable taxa, such as Noaea mucronata (Forssk.) Asch. \& Schweinf. and Anabasis spp. (HCDS, 2010). For these reasons, a protection strategy should be undertaken for this species, and a characterisation of its genetic structure is necessary as a basis for conservation policies.

Karyological and cytogenetic data are fundamental for characterising genome organisation, which is key for systematic, evolutionary, and conservation approaches to plant studies (Levin, 2002). Chromosome number is a basic, but also a relevant trait for plant systematic and evolutionary studies, since it allows detecting evolution-driving processes, such as polyploidy and disploidy (Stebbins, 1971; Guerra, 2008; Stuessy, 2009, 2011; Garbari \& al., 2012). Genome size is also a crucial cytological parameter because it is related to many others and sometimes also to systematic, ecological and other factors (Bennett \& Leitch, 2005). Molecular cytogenetics, and particularly fluorescent in situ hybridisation (FISH), offer powerful tools for a deep karyotype analysis, by providing physical maps for some chromosomal regions and allowing to infer mechanisms of chromosomal evolution, such as different kinds or rearrangements (SiljakYakovlev \& al., 2014). The genus Artemisia has been largely studied from this point of view (Vallès \& al., 2011), but the $A$. herba-alba complex still needs attention in this subject: despite its large distribution area only a few works on chromosome counts are available (Vallès, 1987; Torrell \& Vallès, 1995; Ferchichi, 1997; Bougoutaia \& al., 2014) and even less on more in depth karyological or cytogenetic approaches (Vallès, 1987; Torrell \& Vallès, 2001; Torrell \& al., 2003).

This paper performs a karyological and cytogenetic investigation of a representative set of Algerian populations of $A$. herba-alba, with the aim to provide a comprehensive picture of its genome organisation, which could serve as the basis for further genetic studies and for the conservation and management of this species. Specifically, the objectives were to: 1) estimate the genome size, 2) determine chromosome number, 3) establish the karyotype, 4) physically map rRNA genes in chromosomes, and 5) assess any differences in the above characters in populations with different degrees of conservation.

\section{MATERIAL AND METHODS}

\section{Plant material}

Achenes and/or fresh leaves were collected from several individuals of twenty-two $A$. herba-alba populations, representing a large sorting of the species in Algeria
(Table 1, Fig. 1). Vouchers were prepared and deposited in the herbarium BCN, of the Centre de Documentació de Biodiversitat Vegetal (Universitat de Barcelona).

\section{Genome size assessment}

Nuclear DNA content of each population was estimated by flow cytometry at the Centres Científics i Tecnologics (Universitat de Barcelona). Fresh leaf material, directly collected in the field or obtained from seedlings from germinated achenes, was chopped with a razor blade together with leaf material of an internal standard in 1,200 $\mu \mathrm{l}$ of LB01 buffer (Doležel \& al., 1989), supplemented with $100 \mu \mathrm{g} / \mathrm{ml}$ of ribonuclease A (RNase A, Boehringer). The resulting liquid was filtered and the nuclei suspension was stained with 36 $\mu \mathrm{l}$ of propidium iodide $(1 \mathrm{mg} / \mathrm{ml}$, Sigma-Aldrich Química, Madrid, Spain) to a final concentration of $60 \mu \mathrm{g} / \mathrm{ml}$ and kept on ice for 5-20 min. Measurements were carried out with an Epics XL (Coulter Corporation, Hialeah, Florida, USA), with the following configuration of the instrument: excitation of the sample was carried out using a standard $488 \mathrm{~nm}$ air-cooled argon-ion laser at $15 \mathrm{~mW}$ power; forward scatter (FCS), side scatter (SSC) and red $(620 \mathrm{~nm})$ fluorescence (FL3) for propidium iodide were acquired. Cells were triggered using the FL3. Although FSC is conventionally used to trigger all, the use of FL3 channel as a triggering parameter allows to discard all particles that do not correspond to nuclei. In order to remove background from nuclei, a consecutive gating strategy of FCS vs FL3log and SSC vs FL3 $\log$ was used. Finally, FL3 linear histogram was used to assess the DNA content of samples. One run was done per preparation, in which 8000 particles were measured, meaning a minimum of 2000-3000 of them per each fluorescence peak (Artemisia and standard). Two independent replicates of each individual and five individuals per population were analysed. The analyses for a given population were all performed on the same day. Petunia bybrida Vilm. 'PxPc6' and Pisum sativum L. 'Express long' $(2 \mathrm{C}=2.85 \mathrm{pg}$ and $8.37 \mathrm{pg}$, respectively; Marie \& Brown, 1993) were used as internal standards. Seeds of the standards were provided by the Institut des Sciences du Végétal (CNRS, Gif-sur-Yvette, France). Nuclear DNA contents (2C) were calculated by multiplying the known DNA content of the standard by the quotient between the peak positions (mode) of the target species and the standard in the histogram of fluorescence intensities, assuming a linear correlation between the fluorescent signals from the stained nuclei of the unknown specimen, the known internal standard, and the DNA amount (Doležel, 1991). From the holoploid 2C value estimated as described above, we calculated the monoploid $1 \mathrm{Cx}$ value by dividing the latter by the ploidy level (Greilhuber $\&$ al., 2005).

\section{Chromosome counting}

Root tips were pre-treated with $0.05 \%$ aqueous colchicine for $2 \mathrm{~h} 15 \mathrm{~min}-2 \mathrm{~h} 45 \mathrm{~min}$ at room temperature and fixed in absolute ethanol and glacial acetic acid (3:1) at room temperature for $1-2 \mathrm{~h}$, then kept in the same fixative at $4^{\circ} \mathrm{C}$. For chromosome counts, root tips meristems were excised, hydrolysed for $1.5-2 \mathrm{~min}$ on $1 \mathrm{M} \mathrm{HCl}$ at $60^{\circ} \mathrm{C}$, washed with 


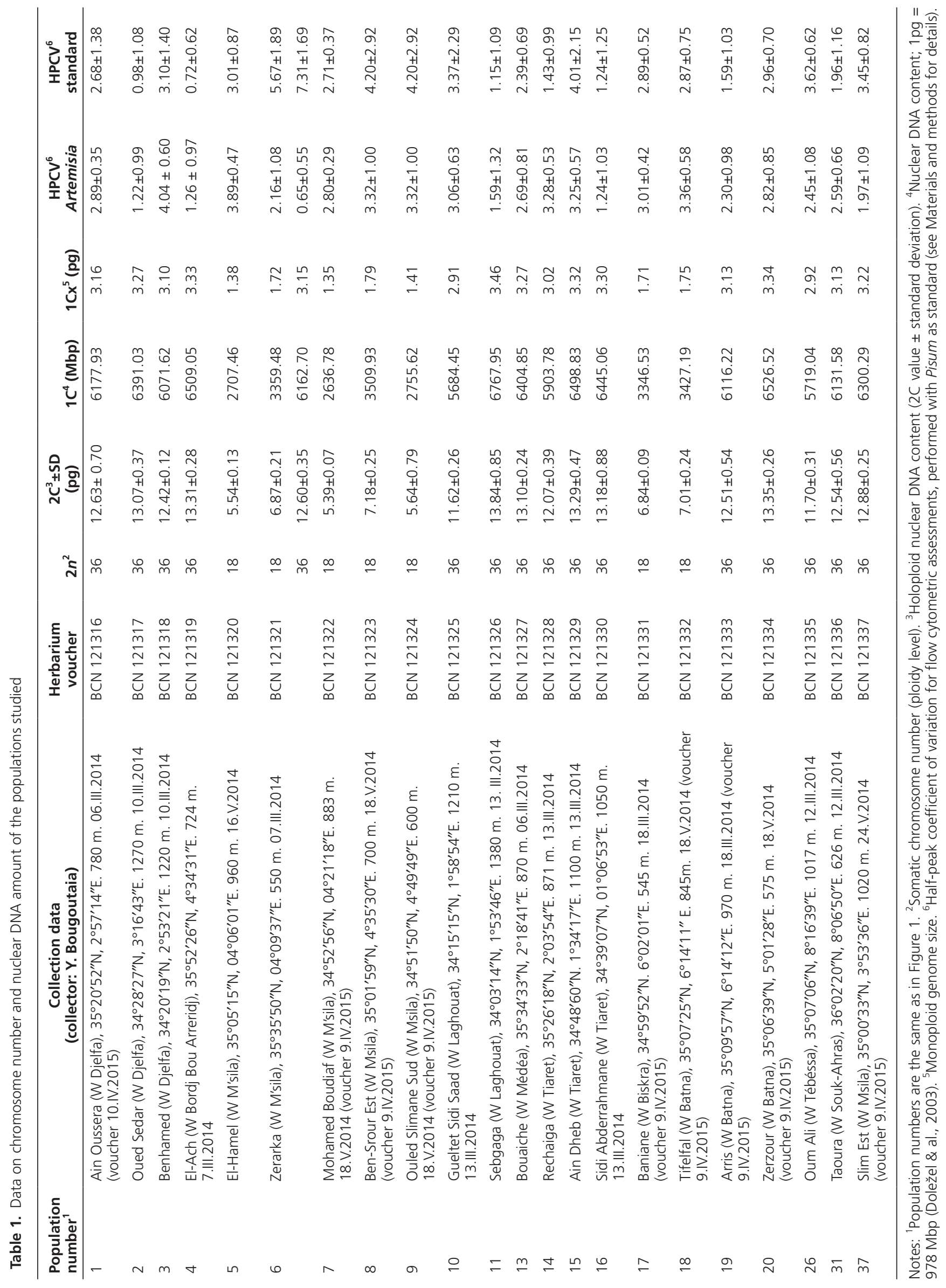




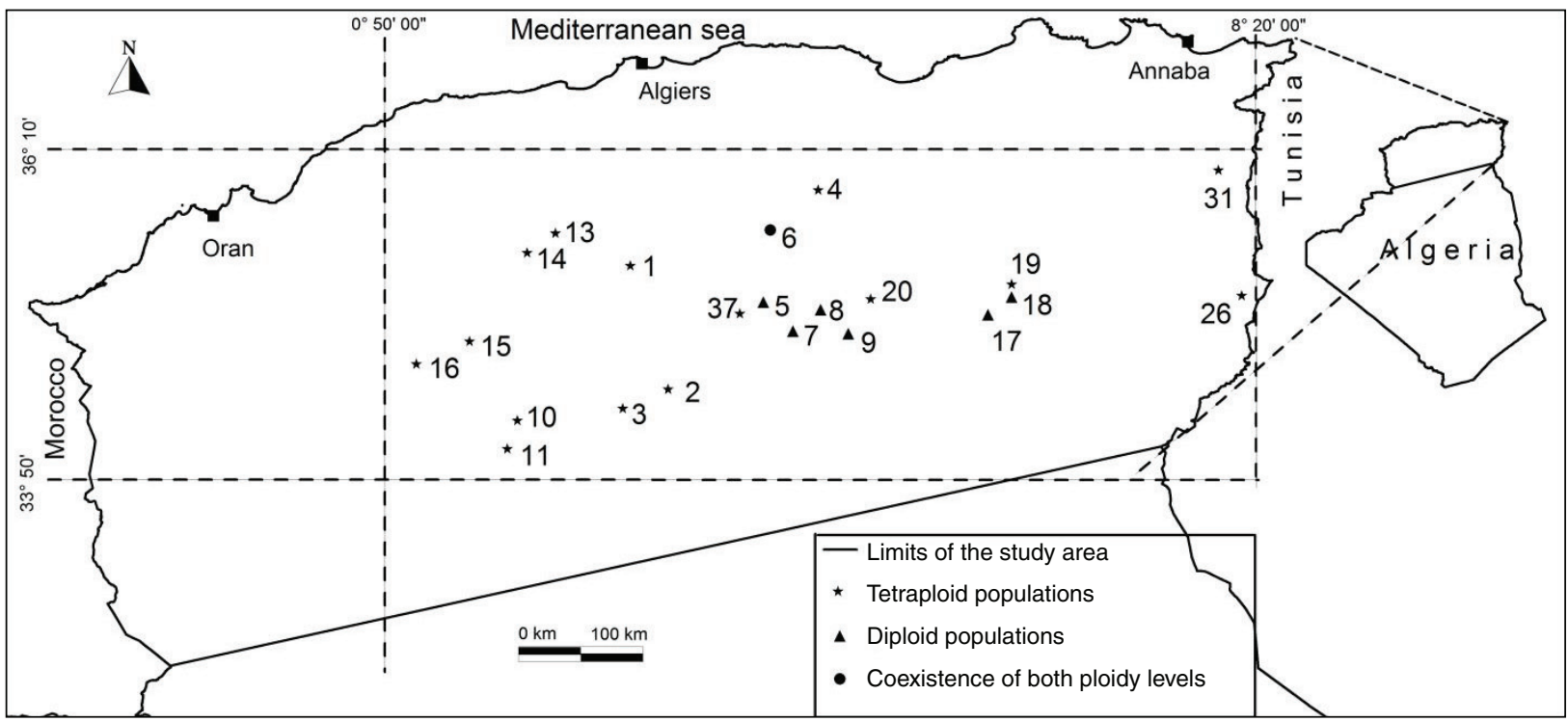

Fig. 1. Geographical location of the populations studied.

distilled water, stained on $2 \%$ aceto-orcein and squashed on a drop of 9:1 45\% acetic acid:glycerol. Slides were observed with a Zeiss Axioplan microscope and the best metaphase plates were photographed with an AcioCam HRm camera.

\section{Fluorescent in situ hybridisation (FISH)}

FISH for the detection of 35S (45S; 18S-5.8S-26S) and $5 \mathrm{~S}$ rDNA loci was performed in one population for every detected ploidy level. To obtain protoplasts, root tips pretreated and fixed as mentioned above were washed in 0.01 $\mathrm{M}$ citric acid-sodium citrate buffer $(\mathrm{pH} 4.6)$ for $10 \mathrm{~min}$ and digested in an enzyme mixture [3\% cellulase "Onozuka" R-10 (Yakult Honsha Co. Tokyo, Japan) and 30\% pectinase (Sigma) or 4\% cellulase "Onozuka" R-10 (Yakult Honsha Co. Tokyo, Japan), 1\% pectolyase Y-23 (Seishin Co. Tokyo, Japan), and $4 \%$ hemicellulase (Sigma)] diluted at $50 \%$ in citrate buffer, for $30 \mathrm{~min}$ at $37^{\circ} \mathrm{C}$. Then, they were rinsed with distilled water and squashed on a drop of freshly prepared $45 \%$ acetic acid; the coverslips were removed after freezing and air dried. The probe used for $35 \mathrm{~S}$ rDNA localisation was a plasmid carrying a $2.5 \mathrm{~kb}$ insert of $26 \mathrm{~S}$ rRNA gene from Solanum lycopersicum L. labelled with Cy3 (Jena Biosciences) using the Nick Translation Mix (Roche). The $5 \mathrm{~S}$ rDNA probe was an approximately $0.7 \mathrm{~kb}$-long trimer of $5 \mathrm{~S}$ rRNA genes from $A$. tridentata Nutt., labelled with Green dUTP using the Nick Translation Mix (Abbott Molecular). This probe contained three units of the $5 \mathrm{~S}$ rRNA gene (120 bp) and the non-coding intergenic spacers (about 290 bp). FISH was carried out according to Gouja \& al. (2015). Samples were counterstained with Vectashield (Vector Laboratories, Inc., Burlingame, CA, USA), a mounting medium containing $500 \mathrm{ng} / \mathrm{\mu l}$ of 4',6-diamidino-2-phenylindole (DAPI). The fluorescence signals were analysed and photographed using a digital camera (AxioCam HRm, Zeiss) coupled to a Zeiss Axioplan microscope; images were analysed with Axiovision HR Rev3, version 4.8 (Zeiss) and processed for colour balance, contrast and brightness uniformity in Adobe Photoshop. The data were submitted to the Plant rDNA database, a database compiling information on rDNA signal number, position and organisation (Garcia \& al., 2012).

\section{Karyological analyses}

Pictures of 3-6 metaphase plates with a similar degree of chromosome condensation were used to calculate karyotype data and elaborate idiograms in three populations, representing both ploidy levels. Morphometric karyotypic parameters were calculated with MicroMeasure 3.3 (Colorado State University). Graphics of the haploid idiograms were performed with PowerPoint (Microsoft Office 2010).

\section{Statistical analyses}

A one-way ANOVA was used to analyse interpopulation variation of genome size within both ploidy levels. Bonferroni tests for mean comparisons were also carried out. Statistical analyses were performed with XLSTAT-Pro, v.7.5.2 (Addinsoft).

\section{RESULTS AND DISCUSSION}

Chromosome number and nuclear DNA amount data of the 22 accessions studied are presented in Table 1. Table 2 contains karyotype morphometric data and rDNA FISH results obtained in selected populations, comprising both ploidy levels found. Fluorescence histograms for each ploidy level are provided in Fig. 2.

\section{Ploidy level variation and its relationships with distribution and conservation status}

The studied accessions are diploid $-2 n=2 x=18$ chromosomes, 6 populations- or tetraploid $-2 n=4 x=36$ chromosomes, 15 populations-, one of them - number 6- presenting both ploidy levels; additionally, a few counts 
Table 2. Summary of karyological results. The superscripts indicate: ${ }^{1}$ chromosomal formula according to Levan \& al. (1964); ${ }^{2}$ total karyotype length; ${ }^{3}$ mean chromosome length; ${ }^{4}$ chromosome length range; ${ }^{5}$ standard deviation; ${ }^{6}$ length ratio of long and short chromosome arms (Levan \& al., 1964); ${ }^{7}$ centromeric index [I or index in Levan \& al. (1964)]; ${ }^{8}$ intrachromosomal asymmetry index (Romero, 1986); ${ }^{9}$ interchromosomal asymmetry index (Romero, 1986); ${ }^{10}$ symmetry class according to Stebbins (1971); ${ }^{11} \mathrm{FISH}$ results (number of colocalised $35 \mathrm{~S}$ and $5 \mathrm{~S}$ loci). Karyological results correspond to populations 06 ( $2 x$ and $4 x), 17$ and 26 , and FISH results correspond to populations $17(2 x)$ and $26(4 x)$.

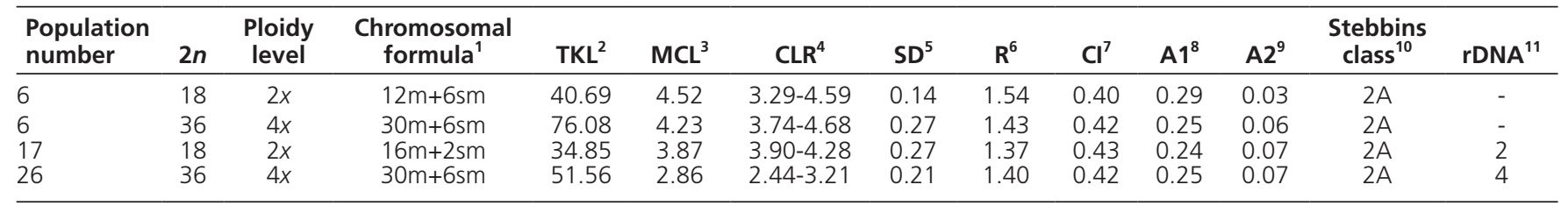

(a)

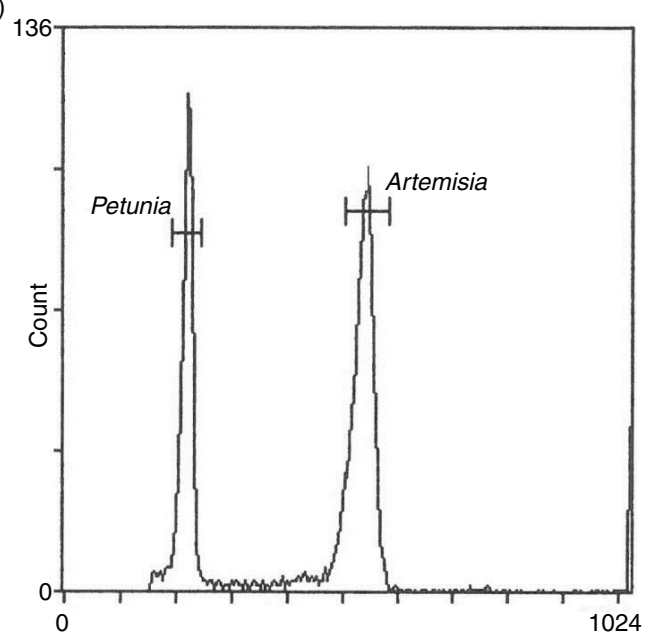

(b)

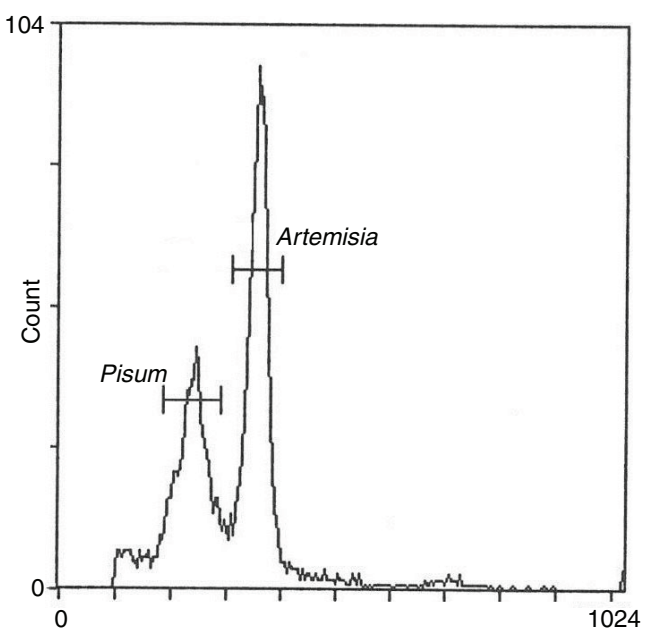

Fig. 2. Fluorescence histograms of genome size assessments by flow cytometry using propidium iodide: a, Artemisia herba-alba (diploid individuals of population $\mathrm{n} .{ }^{\circ} 6 ; 2 \mathrm{C}=6.87 \mathrm{pg}$ ) with Petunia $\left(2 \mathrm{C}=2.85 \mathrm{pg}\right.$ ) as internal standard; $\mathbf{b}$, $A$. herba-alba (tetraploid population $\mathrm{n} .^{\circ} 15 ; 2 \mathrm{C}=13.29 \mathrm{pg}$ ) with Pisum $(2 \mathrm{C}=8.37 \mathrm{pg})$ as internal standard.

could also suggest the existence of polyploid individuals in population number 5 although genome size assessments indicate only diploids (Bougoutaia, unpubl. data). The results are coincidental with previous counts on this taxon, which already revealed the existence of two ploidy levels (Vallès \& al., 2011). According to Watanabe's Index to Chromosome Numbers in Asteraceae (Watanabe, 2015), our study contributes the first diploid chromosome number for $A$. herba-alba from Algeria. From this country, only tetraploid cytotypes were previously recorded, after cytogenetic analysis of 10 populations (Betina \& al., 2007; Bougoutaia \& al., 2014). In Morocco, only the diploid level has been reported (Kawatani \& Ohno, 1964; Ouyahya \& Viano, 1988), whereas in Tunisian populations either diploid (Vallès \& Torrell, 1995) or diploid and tetraploid (Ferchichi, 1997) cytotypes have been reported. A similar situation has been described for the northern part of the Mediterranean basin, in the Iberian Peninsula, where both cytotypes also coexist (Vallès, 1987). The karyotypes (Table 2, Fig. 3) are rather symmetric (2A asymmetry class; Stebbins, 1971), in agreement with the most common pattern in the genus (Vallès \& al., 2011).

Polyploidy is one of the main evolutionary drivers in plants (Cui \& al., 2006; Soltis \& al., 2009) and is very common in Artemisia, where ploidy levels up to $16 x$ have been reported (Pellicer \& al., 2010). The polyploid North African populations of $A$. herba-alba reflect a process of genome differentiation. The same situation in Iberian accessions has led to the consideration of two taxa, separated either at specific or at subspecific levels [2x: A. valentina Lam., A. herba-alba subsp. valentina (Lam.) Mascl.; $4 x$ : A aragonensis Lam., A. berba-alba subsp. herba-alba], although their morphological distinction is very difficult (Vallès, 1987). The coexistence of diploid and tetraploid individuals in one population and the possibility of this being the case for another one is not rare in Artemisia, since some populations with mixed ploidy levels have been detected in other species (Kreitschitz \& Vallès, 2003; Garcia \& al., 2009a), and could be interpreted as a sign of genome dynamism that might be associated to some degree of differentiation.

Out of the 22 populations studied, $12-2-4,6,10,11$, 13-16, 26, and 31- are in a rather good state of conservation, since they are located in areas protected by the HCDS, whereas the remaining $10-1,5,7-9,17-20$, and $37-$ are in a more or less advanced degradation situation outside these protected areas. All populations in the HCDS areas are tetraploid -excepting population 6, which presents both diploid and tetraploid individuals-, while those populations in the degraded areas are mostly diploid $-60 \%$ There is no significant difference in genome size among tetraploids from the degraded populations and the preserved ones $(p=0.760)$. Interestingly, all diploid populations are only found in arid environments while the tetraploid ones 
(a)

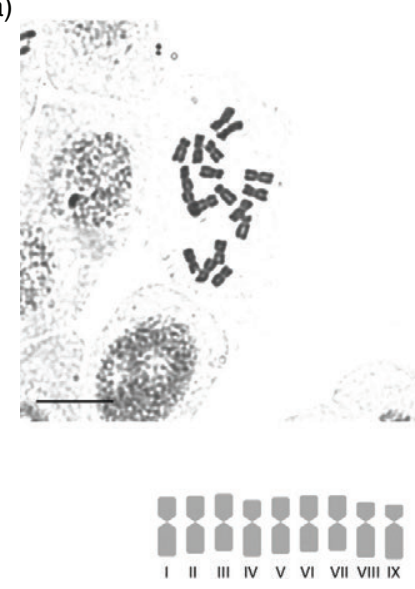

(c)
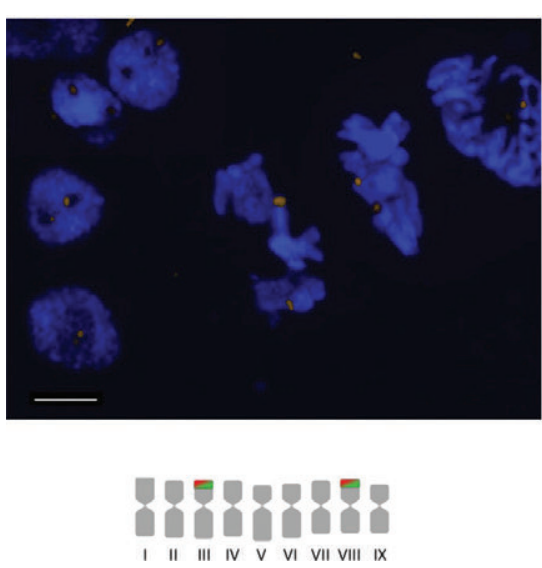

(b)
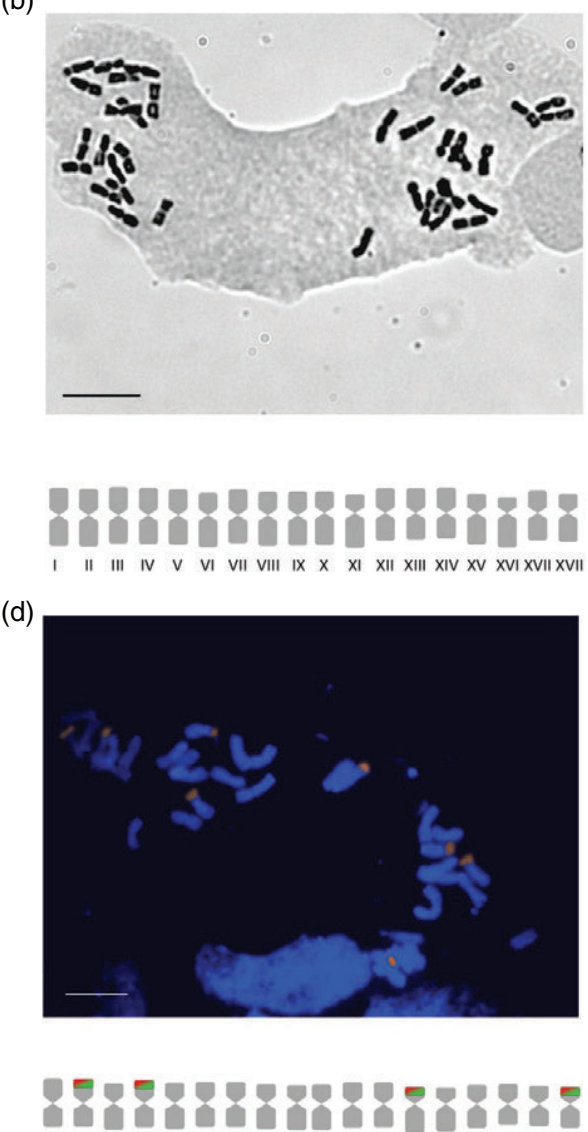

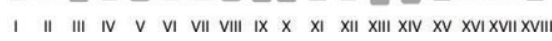

Fig. 3. Orcein-stained somatic metaphases and haploid idiograms of a diploid (a) and a tetraploid (b) individual (both from population 6), and somatic metaphases submitted to fluorescence in situ hybridisation with haploid idiograms showing the rDNA location in one diploid (c) and one tetraploid (d) individual (from populations 17 and 26 respectively). Scale bars, $10 \mu \mathrm{m}$.

are found in both arid and semi-arid environments. In fact, all diploid populations grow in an arid corridor, whereas no polyploid population does; even polyploid populations growing relatively close to diploid ones, such as 20 and 37, are not under strictly arid conditions. Diploids may thus be specifically adapted to arid conditions while the bioclimatic range of tetraploids is wider. This could explain why diploid populations occupy only the central part of the studied area, whereas polyploid ones are distributed both in this central part and in other zones. Polyploidy confers evolutionary advantages derived from an increased genetic endowment and hence potential for variability. This can generate individuals capable of exploiting new niches (Leitch \& Leitch, 2008). Lumaret \& al. (1987) found that diploid populations of Dactilis glomerata L. were confined to habitats of ancient origin, while tetraploids were widespread. Polyploids may be more successful colonizers after glacial periods than their closely related diploids (Brochmann \& Brysting, 2004) because polyploidy would contribute to their environmental stress tolerance and to their larger expansion.

\section{Genome size}

Nuclear DNA amounts (Table 1), evaluated here for the first time in North African representatives of the taxon, ranged from 5.39 to $7.18 \mathrm{pg}$ for diploid accessions and from
11.62 to $13.84 \mathrm{pg}$ for tetraploids. These results are similar to those obtained in Iberian populations (Torrell \& Vallès, 2001), where 2C values of 6.57 and 12.48 pg were obtained for diploid and tetraploid accessions, respectively. Genome size in both Iberian and Algerian populations reflects well the two ploidy levels, with almost no downsizing with polyploidy. Although a relative decrease in nuclear DNA content is frequent in polyploids (Leitch \& Bennett, 2004), Pellicer \& al. (2010) found no genome downsizing in the South American endemic $A$. mendozana DC., and attributed this phenomenon to a recent polyploidy event, which could be the case as well here. However, in the North American $A$. subgenus Tridentatae (Rydb.) McArthur (A. sect. Tridentatae Rydb., basion.), Garcia \& al. (2008) reported both decrease and conservation of genome size in whole genome duplicated genomes.

The expected nuclear DNA amount differences between diploids and polyploids have been addressed in the ploidy level variation section. In addition, significant differences in genome size were observed within both diploid and polyploid populations. The ANOVA test shows significant differences in genome size within diploid level $-\mathrm{F}=26.224$, $\mathrm{p}<0.0001$ - with two groups clearly differentiated in Bonferroni test, the first one comprising populations 6, 8, 17 and 18 and the second one including populations 5, 7 and 9. In the tetraploid level the observed differences are also 
significant $-\mathrm{F}=8.106, \mathrm{p}<0.0001-$. The mean comparison test indicates that the DNA amount from population 11 differs significantly from populations 10 and 26 .

These intra-ploidy level differences do not seem to be directly associated to environmental factors such as altitude or climate, nor to geography and thus are not easy to explain. For example, the highest genome size in tetraploids corresponds to population 11, growing at $1386 \mathrm{~m}$ a.s.l. and the lowest one to population 10, growing at 1210, the two highest altitudes for all the studied populations. Both populations are geographically close to each other and at similar altitudes; population 11 grows in a mountain habitat with very cold winters, whereas population 10 is located in a high plain, where winters could be slightly milder. Also, the population with the second lowest genome size among the tetraploids -10 , with a very similar value to 6 - is located near Tunisia, at $1070 \mathrm{~m}$ and in the opposite side of the study area. Similarly, climatic conditions do not seem to explain genome size differences in the rest of our data. Duchoslav \& al. (2013) also showed that environmental variables were not relevant in modulating genome size in Allium oleraceum L.

Such significant differences in GS within each ploidy level could be due to a few chromosome losses, gains, rearrangements, or to changes in chromosome dimensions. At a first glance, aneuploidy/dysploidy is not the most likely of those possible causes, since all the numerous chromosome counts in $A$. herba-alba reported $2 n=18$ or $2 n=36$ chromosomes (Watanabe, 2015) and since the subgenus Seriphidium, to which this species belongs, has been largely studied and is, in fact, one of the few groups in Artemisia lacking dysploidy (Vallès \& al., 2011). To shed light on this matter, further studies will be undertaken focusing on a deep analysis of karyotypic features.

\section{rDNA physical mapping}

FISH analyses (Table 2, Fig. 3), performed for the first time in North African materials of the taxon, detected 4 signals (2 loci) in diploid and 8 signals (4 loci) in tetraploid cytotypes for both $35 \mathrm{~S}$ and $5 \mathrm{~S}$ rDNA, which are colocalised, presenting an L-type (linked) organisation. This agrees with the only previous FISH data in the species, made on Iberian populations: 4 signals were detected in the diploid accession studied for both $35 \mathrm{~S}$ and $5 \mathrm{~S}$ rDNA and 8 signals were reported in the tetraploid population (for $35 \mathrm{~S}$ only). Colocalisation of $35 \mathrm{~S}$ and $5 \mathrm{~S}$ rDNA genes found in our study is in agreement with the first report within Artemisia (Torrell \& al., 2001) as well as in $A$. berba-alba itself (Torrell $\&$ al., 2003) and in other species of this genus (Garcia \& al., 2007, 2009b).

\section{Concluding remarks}

This first karyological and cytogenetic study on Algerian $A$. herba-alba, based on an ample number of populations, shows the relevance of polyploidy within this taxon. The presence of two ploidy levels suggests a genomic dynamism and even a possible differentiation underlying the morphological uniformity and despite of the dramatic decrease experienced by this plant in Algeria in terms of surface coverage.
Further studies enlarging the sampling area in order to better assess the distribution limits of the polyploidy cytotypes are needed. Also, population genetic studies focusing on the possible effect of the decrease in surface covered by $A$. berba-alba on the persistence and conservation not only of this species but of the arid zone landscape, which constitutes an important economic resource.

\section{ACKNOWLEDGEMENTS}

This work was supported by the Dirección General de Investigación Científica y Técnica, Spanish government (CGL2013-49097-C2-2-P) and the Generalitat de Catalunya, Catalonian government ("Ajuts a grups de recerca consolidats", 2014SGR514). Y.B. received a grant from the Algerian government for two short stages in coauthors' laboratories in Barcelona. S.G. benefitted from a Juan de la Cierva and Ramón y Cajal contracts from the Ministry of Economy and Competitiveness, Government of Spain. The authors thank Spencer C. Brown (Gif-sur-Yvette) for providing seeds of standards used in flow cytometry, Ricard Àlvarez, Jaume Comas, Chari González and Sonia Ruiz for their assistance in flow cytometric analyses. Two anonymous reviewers and the associate editor Gonzalo Nieto are thanked for their comments, which improved the manuscript.

\section{REFERENCES}

Aidoud, A. 1988. Les écosystèmes steppiques à armoise blanche (Artemisia berba-alba Asso): Caractères généraux. Biocénose: Bulletin d'écologie terrestre 3(12)

Bennett, M.D. \& Leitch, I.J. 2005. Nuclear DNA amounts in angiosperms: progress, problems, prospects. Annals of Botany 95: 45-90. http:// dx.doi.org/10.1093/aob/mci003

Betina, S., Khalfallah, N. \& Khelifi, D. 2007. Étude cytogénétique et biochimique de huit populations d'armoise blanche algérienne Artemisia berba-alba Asso. Revue des Régions Arides 2007(2): 602-607.

Bougoutaia, Y., Nedjimi, B., Adda, A. \& Kaid-Harche, M. 2014. Étude caryologique et moléculaire de deux populations algériennes d'Artemisia berba alba Asso. (Asteraceae). Revue Agriculture 8: 21-25.

Brochmann, C. \& Brysting, A. 2004. Polyploidy in arctic plants. Biological Journal of the Linnean Society 82: 521-536. http://dx.doi. org/10.1111/j.1095-8312.2004.00337.x

Cui, L., Wall, P.K., Leebens-Mack, J.H., Lindsay, B.G., Soltis, D.E., Doyle, J.J., Soltis, P.S., Carlson, J.E., Arumuganathan, K., Barakat, A., Albert, V.A., Ma, H. \& DePamphilis, C.W. 2006. Widespread genome duplications throughout the history of flowering plants. Genome Research 16: 738-749. http://dx.doi.org/10.1101/gr.4825606

Doležel, J. 1991. Flow cytometric analysis of nuclear DNA content in higher plants. Phytochemical Analysis 2: 143-154. http://dx.doi.org/10.1002/ pca.2800020402

Doležel, J., Bartoš, J., Voglmayr, H. \& Greilhuber, J. 2003. Nuclear DNA content and genome size of trout and human. Cytometry 51: 127-128. http://dx.doi.org/10.1002/cyto.a.10013

Doležel, J., Binarová, P. \& Lucretti S. 1989. Analysis of nuclear DNA content in plant cells by flow cytometry. Biologia Plantarum 31: 113-120. http://dx.doi.org/10.1007/BF02907241

Duchoslav, M., Šafářová, L. \& Jandová, M. 2013. Role of adaptive and nonadaptive mechanisms forming complex paterns of genome size variation in six cytotypes of polyploid Allium oleraceum (Amaryllidaceae) on a continental scale. Annals of Botany 111: 419-431. http://dx.doi. org/10.1093/aob/mcs297

Fawcett, J., Van de Peer, Y. \& Maere, S. 2013 Significance and biological consequences of polyploidization in land plant evolution. In: Leitch, I., Greilhuber J., Doležel, J. \& Wendel, J. (eds.), Plant Genome Diversity 2: 277-293. Springer, Vienna.

Ferchichi, A. 1997. Contribution à l'étude cytotaxonomique et biologique d'Artemisia herba-alba Asso en Tunisie présaharienne. Acta Botanica Gallica 144: 145-154. http://dx.doi.org/10.1080/12538078.1997.1051 5761

Garbari, F., Bedini, G. \& Peruzzi, L. 2012. Chromosome numbers of the Italian flora. From the Caryologia foundation to present. Caryologia 65: 62-71. http://dx.doi.org/10.1080/00087114.2012.678090

Garcia, S., Canela, M.Á., Garnatje, T., McArthur, E.D., Pellicer, J., Sanderson, S.C. \& Vallès, J. 2008. Evolutionary and ecological implications of genome size in the North American endemic sagebrushes and 
allies (Artemisia, Asteraceae). Biological Journal of the Linnean Society 94: 631-649. http://dx.doi.org/10.1111/j.1095-8312.2008.01001.x

Garcia, S., Garnatje, T., Hidalgo, O., Siljak-Yakovlev, S. \& Vallès, J. 2007. Extensive ribosomal DNA (18S-5.8S-26S and 5S) colocalization in the North American endemic sagebrushes (subgenus Tridentatae, Artemisia, Asteraceae) revealed by FISH. Plant Systematics and Evolution 267: 79-92. http://dx.doi.org/10.1007/s00606-007-0558-6

Garcia, S., Garnatje, T. \& Kovarik, A. 2012. Plant rDNA database: ribosomal DNA loci information goes online. Chromosoma 121: 389-394. http://dx.doi.org/10.1007/s00412-012-0368-7

Garcia, S., Garnatje, T., Pellicer, J., McArthur, E.D., Siljak-Yakovlev, S. \& Vallès, J. 2009a. Ribosomal DNA and genome size changes during polyploid and hybrid formation in the North American endemic sagebrushes (Tridentatae, Artemisia). Genome 52: 1012-1024. http://dx.doi. org/10.1139/G09-077

Garcia, S., Lim, K.Y., Chester, M., Garnatje, T., Pellicer, J., Vallès, J., Leitch, A.R. \& Kovařík, K. 2009b. Linkage of 35S and 5S rRNA genes in Artemisia (family Asteraceae): first evidence from angiosperms. Chromosoma 118: 85-97. http://dx.doi.org/10.1007/s00412-008-0179-z

Gouja, H., Garnatje, T., Hidalgo, O., Neffati, M., Raies, A. \& Garcia, S. 2015. Physical mapping of ribosomal DNA and genome size in diploid and polyploid North African Calligonum species (Polygonaceae). Plant Systematics and Evolution 301: 1569-1579. http://dx.doi.org/10.1007/ s00606-014-1183-9

Greilhuber, J., Doležel, J., Lysák, M. \& Bennett, M.D. 2005. The origin, evolution, and proposed stabilization of the terms 'genome size' and 'C-value' to describe nuclear DNA contents. Annals of Botany 95: 255 260. http://dx.doi.org/10.1093/aob/mci019

Guerra, M. 2008. Chromosome numbers in plant cytotaxonomy: Concepts and implications. Cytogenetics and Genome Research 120: 339-350. http://dx.doi.org/10.1159/000121083

HCDS. 2010. Les potentialités agro-pastorales de la steppe Algérienne. Analyse et interprétation des résultats de l'étude. Rapport d'étude. Haut commissariat au développement de la steppe (HCDS), Djelfa.

Houmani, M., Houmani, Z. \& Skoula, M. 2004. Intérêt de Artemisia herbaalba Asso dans l'alimentation du bétail des steppes algériennes. Acta Botanica Gallica 151: 165-172. http://dx.doi.org/10.1080/12538078.20 04.10516031

Kawatani, T. \& Ohno, T. 1964. Chromosome numbers in Artemisia. Bulletin of the National Institute for Hygienic Sciences 82: 183-193.

Kreitschitz, A. \& Vallès, J. 2003. New or rare data on chromosome numbers in several taxa of the genus Artemisia (Asteraceae) in Poland. Folia Geobotanica 38: 333-343.http://dx.doi.org/10.1007/BF02803203

Leitch, A.R. \& Leitch, I.J. 2008. Genomic plasticity and the diversity of polyploid plants. Science 320: 481-483. http://dx.doi.org/10.1126/ science. 1153585

Leitch, I.J. \& Bennett, M.D. 2004. Genome downsizing in polyploid plants. Biological Journal of the Linnean Society 82: 651-663. http://dx.doi. org/10.1111/j.1095-8312.2004.00349.x

Levan, A., Fredga, K. \& Sandberg, A.A. 1964. Nomenclature for centromeric position on chromosomes. Hereditas 52: 201-220. http://dx.doi. org/10.1111/j.1601-5223.1964.tb01953.x

Levin, D.A. 2002. The role of chromosomal changes in plant evolution. Oxford University Press, Oxford.

Lumaret, R., Guillerm, J.L., Delay, J., Loutfi, A.A.L., Izco, J. \& Jay, M. 1987. Polyploidy and habitat differentiation in Dactylis glomerata L. from Galicia (Spain). Oecologia 73: 436-446. http://dx.doi.org/10.1007/ BF00385262

Marie, D. \& Brown, S.C. 1993. A cytometric exercise in plant DNA histograms, with 2C values for 70 species. Biology of the Cell 78: 41-51. http://dx.doi.org/10.1016/0248-4900(93)90113-S

Nedjimi, B. \& Guit, B. 2012. Les steppes algériennes: causes de déséquilibre. Algerian Journal of Arid Environments 2: 50-61.
Ouyahya, A. \& Viano, J. 1988. Recherches cytogénétiques sur le genre Artemisia L. au Maroc. Boletim da Sociedade Broteriana série 2, 61: 105-124.

Pellicer, J., Garnatje, T., Molero, J., Pustahija, F., Siljak-Yakovlev, S. \& Vallès, J. 2010. Origin and evolution of the South American endemic Artemisia species (Asteraceae): evidence from molecular phylogeny, ribosomal DNA and genome size data. Australian Journal of Botany 58: 605-616. http://dx.doi.org/10.1071/BT10047

Podlech, D. 2013. Some remarks on Artemisia subgenus Seriphidium (Asteraceae) mostly from Afghanistan. Rostaniba 14: 48-58.

Pouget M. 1980. Les relations sol-végétation dans les steppes sud-algéroises. ORSTOM (collection "Travaux et Documents"), Paris.

Romero, C. 1986. A new method for estimating karyotype asymmetry. Taxon 35: 526-530. http://dx.doi.org/10.2307/1221906

Siljak-Yakovlev, S., Pustahija, F., Vicic, V. \& Robin, O. 2014. Molecular cytogenetics (FISH and fluorochrome banding): resolving species relationships and genome organization. Methods in Molecular Biology 1115: 309-323. http://dx.doi.org/10.1007/978-1-62703-767-9_15

Soltis, D.E., Albert, V.A., Leebens-Mack, J., Bell, C.D., Paterson, A.H., Zheng, C., Sankoff, D., Depamphilis, C.W., Wall, P.K. \& Soltis, P.S. 2009. Polyploidy and angiosperm diversification. American Journal of Botany 96: 336-348. http://dx.doi.org/10.3732/ajb.0800079

Stebbins, G.L. 1971. Chromosomal evolution in higher plants. Edward Arnold, London.

Stuessy, T.F. 2009. Plant taxonomy. The systematic evaluation of comparative data, ed. 2. Columbia University Press, New York.

Stuessy, T.F. 2011. Multiple sources of comparative data for creative monography. In: Stuessy, T.F. \& Lack, H.W. (eds.), Monographic plant systematics. Fundamental assessment of plant biodiversity: 33-47. Ruggell ARG Ganeter Verlag KG.

Torrell, M., Cerbah, M., Siljak-Yakovlev, S. \& Vallès, J. 2001. Étude cytogénétique de trois taxons du complexe d'Artemisia campestris L. (Asteraceae, Anthemideae): localisation de l'hétérochromatine et de l'ADN ribosomique. Bocconea 13: 623-628.

Torrell, M., Cerbah, M., Siljak-Yakovlev, S. \& Vallès J. 2003. Molecular cytogenetics of the genus Artemisia (Asteraceae, Anthemideae): fluorochrome banding and fluorescent in situ hybridization. I. Subgenus Seriphidium and related taxa. Plant Systematics and Evolution 239: 141153. http://dx.doi.org/10.1007/s00606-002-0259-0

Torrell, M. \& Vallès, J. 2001. Genome size in 21 Artemisia L. species (Asteraceae, Anthemideae): Systematic, evolutionary, and ecological implications. Genome 44: 231-238. http://dx.doi.org/10.1139/ gen-44-2-231

Vallès, J. 1987. Contribución al estudio de las razas ibéricas de Artemisia berba-alba Asso. Boletim da Sociedade Broteriana série 2, 60: 5-27.

Vallès, J. \& Torrell, M. 1995. Reports (552-558). In: Kamari, G., Felber, F. \& Garbari, F. (eds.), Mediterranean chromosome number reports-5. Flora Mediterranea 5: 357-363.

Vallès, J., Garcia, S., Hidalgo, O., Martín, J., Pellicer, J., Sanz, M. \& Garnatje, T. 2011. Biology, genome evolution, biotechnological issues, and research including applied perspectives in Artemisia (Asteraceae). Advances in Botanical Research 60: 349-419. http://dx.doi.org/10.1016/ B978-0-12-385851-1.00015-9

Watanabe, K. [2015]. Index to Chromosome Numbers in Asteraceae (http:// www.lib.kobe-u.ac.jp/infolib/meta_pub/G0000003 asteraceaeresult-en, accessed November 4, 2015)
Associate Editor: Gonzalo Nieto Received: 26-V-2015 Accepted: 21-XII-2015 